\title{
ANALISIS KANDUNGAN KLOROFIL PADA BERBAGAI POSISI DAUN DAN ANAK DAUN AREN (Arrenga pinnata)
}

\author{
Olvia Putri Gracelyta Lawendatu ${ }^{1 *}$, Julius Pontoh ${ }^{1}$ dan Vanda S. Kamu ${ }^{1}$ \\ ${ }^{1}$ Jurusan Kimia Fakultas Matematika dan Ilmu Pengetahuan Alam Universitas Sam Ratulangi, \\ Jl. Kampus Unsrat, Kleak, Manado 95115 Sulawesi Utara
}

\begin{abstract}
ABSTRAK
Telah dilakukan penelitian tentang analisis kandungan klorofil dari berbagai posisi daun dan anak daun dari tanaman aren. Daun aren diambil pada posisi atas, tengah, dan bawah dari tajuk tanaman. Sampel anak daun dibagi 3 posisi yaitu atas, tengah, dan bawah. Ekstraksi dilakukan dengan methanol dan penetuan klorofil pada daun dilakukan dengan spektofotometer pada panjang gelombang $665 \mathrm{~nm}$ dan $652 \mathrm{~nm}$ untuk masing-masing klorofil a dan klorofil b. Kandungan klorofil a dan b yang terdapat pada sampel daun aren yang dihitung berdasarkan 3 unit satuan $\mu \mathrm{g} / \mathrm{mL}, \mathrm{mg} / \mathrm{g}$ dan $\mu \mathrm{mol} / \mathrm{m}^{2}$. Kandungan klorofil a dan b pada sampel pohon aren tertinggi terletak pada posisi kiri daun, pada posisi daun terletak pada daun atas, pada posisi anak daun terletak pada posisi ujung anak daun. Ratio kandungan klorofil pada sampel daun aren berkisar 1,30-6,72.
\end{abstract}

Kata kunci: Klorofil, daun aren, ekstraksi

\section{ABSTRACT}

Has conducted research on the analysis of chlorophyll content from various positions of leaves and leaves of palm plants. Leaves are taken in the top, middle and bottom positions of the plant canopy. Samples of leaflets were divided into 3 positions namely top, middle and bottom. Extraction was carried out with methanol and the determination of chlorophyll in the leaves was carried out by spectrophotometer at wavelengths of $665 \mathrm{~nm}$ and 652 $\mathrm{nm}$ for chlorophyll a and chlorophyll b, respectively. The chlorophyll and b content in palm leaf samples are calculated based on 3 units of $\mu \mathrm{g} / \mathrm{mL}, \mathrm{mg} / \mathrm{g}$, and $\mu \mathrm{mol} / \mathrm{m} 2$. The content of chlorophyll $a$ and $b$ in the highest palm tree sample is located in the left position of the leaf, the position of the leaf is placed on the top of the leaf, the position of the leaflets is placed in the tip of the leaflets. The ratio of chlorophyll content in sugar palm leaf samples in the setting is 1.30-6.72.

Keywords: Chlorophyll, palm leaves, extraction

\section{PENDAHULUAN}

Pohon aren atau enau (Arenga pinnata), Merupakan tumbuhan yang menghasilkan bahanbahan industri sejak lama kita kenal. Hampir semua bagian pohon aren bermanfaat dan dapat digunakan untuk berbagai kebutuhan, mulai dari bagian fisik (akar, batang, daun, ijuk dll) maupun hasil produksinya (nira, pati/tepung dan buah). Hasil produksi aren ini semuanya dapat dimanfaatkan dan memiliki nilai ekonomi. Akan tetapi hasil produksi aren yang banyak diusahakan oleh masyarakat adalah nira yang diolah untuk menghasilkan gula aren dan produk ini memiliki pasar yang sangat luas. Negara-negara yang membutuhkan gula aren dari Indonesia adalah Arab Saudi, Amerika Serikat, Australia, Selandia Baru, Jepang dan Kanada (Sapari, 1994).

Salah satu faktor yang menentukan produksi gula aren yang berasal dari nila aren, yaitu kualitas daunnya. Hal ini disebabkan Karena gula diproduksi pada daun melalui proses fotosintesis dengan menggunakan cahaya matahari sebagai sumber energi. Energi ditangkap oleh klorofil kemudian meneruskannya ke fotosistem.

Klorofil adalah pigmen pemberi warna hijau pada tumbuhan, alga dan bakteri fotosintetik. Klorofil berfungsi untuk menangkap energy dari cahaya (foton) untuk dipindahkan keprotein dalam pusat fotosintesis. Energy ini kemudian digunakan untuk mereduksi air menjadi oksigen dengan menghasilkan electron. Elektron ini akan dilanjutkan untuk proses pembentukan senyawa ATP \& NADPH yang akan memfalitasi pengikatan $\mathrm{CO}_{2}$ menjadi karbohidrat (Voet dkk., 1990).

Klorofil pada tumbuhan terdiri dar klorofil a dan klorofil b. Spektrofotometer klorofil a mempunyai serapan yang maximal pada panjang 
gelombang $665 \mathrm{~nm}$. Sedangkan klorofil mempunyai serapan pada panjang gelombang 652 nm (Voet dkk.,1990). Klorofil adalah senyawa siklik tetrapirol dengan inti (ion $\mathrm{Mg}$ ) yang bersifat nonpolar (klorofil a) dan sedikit polar (klorofil b), itulah sebabnya klorofil larut dalam methanol, alkohol, campuran aseton dan air. Oleh karena itu klorofil iasanya di ekstrak menggunakan pelarutpelarut tersebut (Voet dkk., 1990). Kemampuan tanaman aren untuk memproduksi gula yang sangat tinggi tentunya di tentukan oleh kemampuan tanaman tersebut untuk menyerap energy dari cahaya matahari dengan demikian kandungan klorofil dalam daun aren mempunyai peranan yang sangat penting. Kandungan klorofil dalam satu tanaman berbeda-beda sesuai dengan porsi daun tersebut, misalnya pada daun yang terekspose atau lebih banyak mendapat cahaya matahari mempunyai klorofil yang lebih banyak dibandingkan dengan daun yang kurang mendapat cahaya matahari. Kandungan klorofil pada daun aren telah dilporkan oleh Lidya dkk. (2018) yaitu kandungan klorofil a sebesar 22-39 $\mu \mathrm{g} / \mathrm{mL} ; 1,5-$ $2,3 \mu \mathrm{g} / \mathrm{g} ; 633-1000 \mu \mathrm{mol} / \mathrm{m}^{2}$, sedangkan untuk klorofil $b$ yang terdapat pada daun aren bervariasi sekitar $\quad 6-10 \mu \mathrm{g} / \mathrm{mL} ; \quad 04-0,7 \quad \mathrm{mg} / \mathrm{g} ; \quad 170-293$ $\mu \mathrm{mol} / \mathrm{m}^{2}$. Tujuan penelitian ini adalah untuk menganalisis kandungan klorofil dari berbagai posisi daun dan anak daun dari tanaman aren.

\section{BAHAN DAN METODE}

\section{Bahan dan alat}

Bahan yang digunakan dalam penelitian ini adalah sampel daun aren, standar klorofil a dan klorofil b (Sigma Aldrich), methanol PA(Merck), tissue, akuades, label, dan kantong plastik untuk menyimpan sampel. Alat yang digunakan pada penelitian ini adalah alat-alat gelas, neraca analitik, alat sentrifugasi, lumpang dan alu, lemari pendingin, cool box, alummunium foil, gunting, one hole punch dengan diameter $6,4 \mathrm{~mm}$, alat pengukur panjang, dan spektrofotometer UV-Vis (Shimadzu UV-Vis 1800).

\section{Persiapan sampel}

Persiapan sampel daun aren mengikuti prosedur Porra dkk. (1989). Daun aren diambil pada posisi atas, tengah, dan bawah dari tajuk tanaman. Sampel anak daun dibagi 3 posisi yaitu atas, tengah, dan bawah. Selanjutnya setiap posisi anak daun diambil bagian kiri dan kanan. Lembar daun pada anak daun dibedakan atas 3 bagian, yaitu: pangkal, tengah, dan ujung. Sampel diambil dari setiap bagian tersebut dengan cara dilubangi dengan menggunakan one hole punch. Berat setiap sampel dihitung dari setiap jumlah lingkaran pada sampel yang di ambil. Jumlah lingkaran yang di ambil dari setiap sampel berjumlah 10 lingkaran. Selanjutnya sampel segera diberi label dan diletakkan dalam kantung plastik, kemudian sampel tersebut dimasukkan ke dalam lemari pendingin dengan suhu $\left( \pm 4-10{ }^{\circ} \mathrm{C}\right)$. Lingkaran yang dibentuk oleh one hole punch, dihitung luasnya dengan menggunakan rumus luas lingkaran, yaitu:

$$
\text { Luas lingakaran }=\pi r^{2}
$$

dimana: $\pi=3,14, r=$ jari - jari lingkaran

\section{Ekstraksi sampel dan karakterisasi absorbansi klorofil}

Sampel yang dianalisis diekstrak terlebih dahulu menggunakan metanol (Porra dkk., 1989). Sebanyak 10 lingkaran sampel dan $2 \mathrm{~mL}$ metanol dimasukkan ke dalam wadah lumpang, kemudian dihaluskan dengan cara digerus menggunakan alu. Lalu sampel yang telah digerus dimasukkan ke dalam gelas ukur. Setelah itu, lumpang dan alu yang telah digunakan untuk menghaluskan sampel, dibilas dengan $1,5 \mathrm{~mL}$ metanol sebanyak tiga kali. Tujuannya untuk melarutkan sisa-sisa sampel yang berada didalam lumpang dan alu.

Pelarut yang digunakan untuk membilas sisa-sisa sampel yang terdapat pada lumpang dan alu tersebut, dimasukkan bersama-sama dengan sampel yang telah dihaluskan dengan pelarut tadi ke dalam gelas ukur,dan ditambah metanol hingga mencapai volume $8 \mathrm{~mL}$. Ekstrak tersebut dimasukkan ke dalam tabung centrifuge dan disentrifugasi selama 25 menit dengan kecepatan $1000 \mathrm{rpm}$. Setelah didapatkan filtrat, maka filtrat diambil sebanyak $1 \mathrm{~mL}$ dan dilarutkan ke dalam 4 $\mathrm{mL}$ metanol dan dibaca absorbansinya dengan alat spektrofotometer UV-Vis (Shimadzu UV-Vis 1800) pada panjang gelombang 665 (Klorofil a) dan 652 (Klorofil b).

\section{Analisis konsentrasi klorofil}

Absorbansi yang telah dibaca pada panjang gelombang 665 dan 652 dimasukkan ke dalam rumus menurut Porra dkk.(1989).

$$
\begin{aligned}
& {[\mathrm{Ch} \mathrm{a}]=16,29 A_{665}-8,54 A_{652}} \\
& {[\mathrm{Ch} \mathrm{b}]=30,66 A_{652}-13,58 A_{665}}
\end{aligned}
$$

Dari rumus tersebut didapatkan konsentrasi klorofil yang ada pada daun aren, kelapa, dan kelapa sawit. 


\section{HASIL DAN PEMBAHASAN}

\section{Massa sampel daun aren}

Massa sampel dari anak daun aren yang ditimbang terdiri dari 10 potongan daun aren.

Tabel 1. Massa daun aren per 10 keping sampel (mg)

\begin{tabular}{lc|c|c|c|c|c}
\hline \multirow{2}{*}{ Nama sampel } & \multicolumn{3}{c|}{ Kiri } & \multicolumn{3}{c}{ Kanan } \\
\cline { 2 - 7 } & Pangkal & Tengah & Ujung & Pangkal & Tengah & Ujung \\
\hline Daun atas I & 94 & 85,1 & 93 & 80 & 74,5 & 81,5 \\
Daun tengah I & 106,8 & 98,2 & 88,4 & 93,9 & 88,6 & 75,6 \\
Daun bawah I & 89 & 100,2 & 107,6 & 117,3 & 101,7 & 103,1 \\
Daun atas II & 128 & 199,2 & 129,2 & 108,2 & 119,6 & 107,8 \\
Daun tengah II & 101,8 & 116,3 & 120,7 & 113,9 & 126,3 & 121,1 \\
Daun bawah II & 130,8 & 137,8 & 125,2 & 130 & 130,8 & 131,8 \\
\hline
\end{tabular}

Dari Tabel 1. dapat dilihat bahwa, sampel yang memiliki massa teringan ada pada posisi bagian daun atas. Sendangkan pada posisi anak daun ada pada posisi tengah daun. Selanjutnya, sampel terberat ada pada posisi daun bawah, sedangkna pada posisi anak daun ada pada posisi tengah daun. Dari penenlitian yang telah dilakukan pada perhitungan massa sampel, menunjukkan bahwa sampel yang paling banyak terpapar cahaya matahari, lebih ringan dibandingkan sampel yang kurnag terpapar matahari.

\section{Kandungan klorofil a dan b pada daun aren}

Pada posisi kiri dan kanan anak daun menunjukkan nilai yang signifikan berbeda. Hal ini dapat dilihat pada Gambar 1.

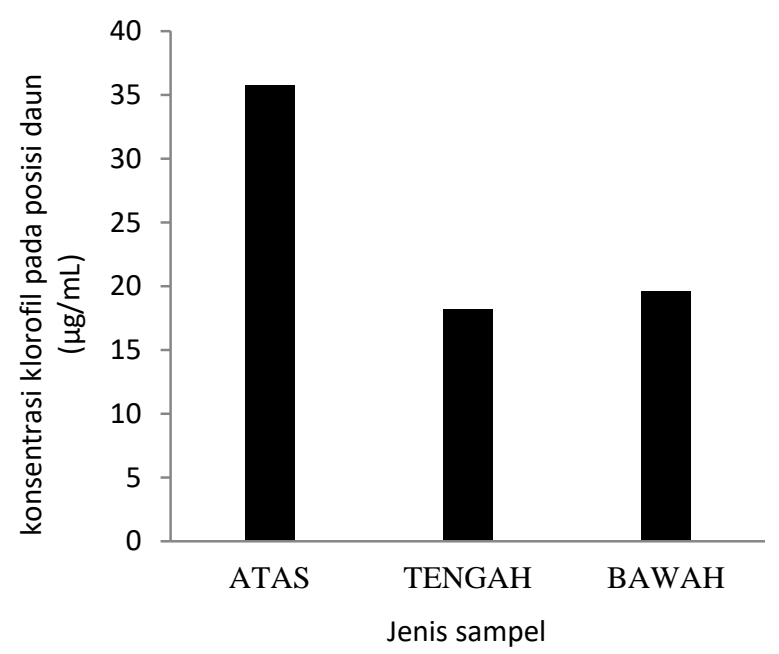

Gambar 1. Jumlah konsentrasi klorofil a pada posisi daun
Dapat dilihat pada Table 1 bahwa massa dari sampel daun aren leih besar terdapat pada sampel daun II, di bandingkan sampel daun I. massa pada sampel daun I berkisar 94-117 mg/keping daun aren sedangkan masa daun II berkisar 101,8-131,8 $\mathrm{mg} / \mathrm{keping}$ daun aren.

Dimana konsentrasi klorofil a pada posisi daun aren memiliki konsentrasi tertinggi terletak pada bagian atas daun, dengan jumlah konsentrasi $35,796 \mu \mathrm{g} / \mathrm{mL}$. sedangkan konsentrasi terendah terletak pada bagian tengah daun dengan jumlah konsentrasi 18,199 $\mu \mathrm{g} / \mathrm{mL}$.

\section{Kandungan klorofil a (mg/g)}

Dapat dilihat bahwa kandungan klorofil a yang dihitung menggunakkan satuan $\mathrm{mg} / \mathrm{g}$ pada pohon I dan pohon II menunjukan perbedaan yang signifikan pada posisi daun, anak daun dan pada posisi kiri dan kanan anak daun aren.hal ini dapat dilihat pada Gambar 2.

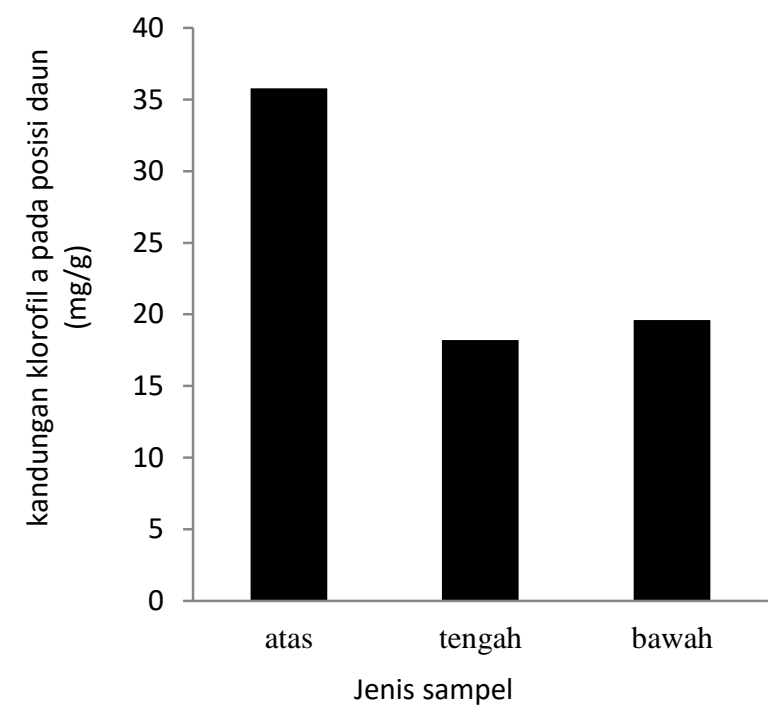

Gambar 2. Kandungan klorofil a pada posisi daun (mg/g). 
Dari Gambar 2 dapat dilihat bahwa kandungan klorofil a yang dihitung menggunakan satuan $\mathrm{mg} / \mathrm{g}$ pada posisi daun (atas, tengah dan bawah). Nilai kandungan klorofil a pada posisi daun aren yang tertinggi berada pada posisi daun atas, dimana nilai dari kandungan daun atas sebesar 35,796 mg/g. Sedangkan nilai pada posisi bagian tengah daun lebih kecil dibandingkan pada posisi bawah daun. Kandungan klorofil pada posisi tengah daun yaitu $18.199 \mathrm{mg} / \mathrm{g}$ sedangkan kandungan klorofil pada posisi bawah yaitu $19,602 \mathrm{mg} / \mathrm{g}$.

\section{Kandungan klorofil a}

Kandungan klorofil pada posisi daun, posisi anak daun, dan posisi kiri dan kanan anak daun aren dapat dilihat pada Gambar 3.

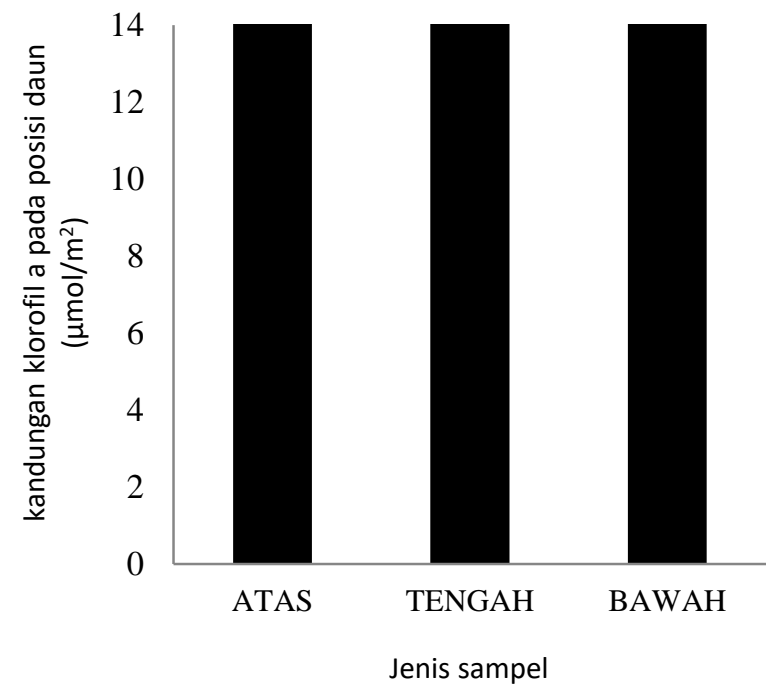

Gambar 3. Kandungan klorofil a pada posisi daun aren $\left(\mu \mathrm{mol} / \mathrm{m}^{2}\right)$.

Dari Gambar 3 dapat dilihat bahwa kandungan klorofil a tertinggi pada posisi daun aren berada pada posisi atas daun, dengan nilai kandungan klorofil yaitu 11,962 $\left(\mu \mathrm{mol} / \mathrm{m}^{2}\right)$. Sedangkan kandungan klorofil a terendah ada pada posisi bawah daun, dengan nilai kandungan klorofil yaitu 5,980 $\left(\mu \mathrm{mol} / \mathrm{m}^{2}\right)$.

\section{Konsentrasi klorofil b $(\mu \mathrm{g} / \mathrm{mL})$}

Konsentrasi klorofil pada posisi daun, posisi anak daun, dan pada posisi kiri dan kanan anak daun aren dapat dilihat pada Gambar 4. Dari Gambar 4 dapat dilihat bahwa konsentrasi klorofil b pada posisi daun, memiliki nilai tertinggi pada posisi atas daun, dengan nilai $12,687 \mu \mathrm{g} / \mathrm{mL}$. Sedangkan konsentrasi klorofil $\mathrm{b}$ terendah ada pada posisi bawah daun, dengan nilai $5,863 \mu \mathrm{g} / \mathrm{mL}$. dapat dilihat bahwa konsentrasi klorfil b pada posisi bawah dan tengah daun tidak memiliki perbedaan yang signifikan. sedangkan pada posisi atas daun memiliki perbedaan yang signifikan.

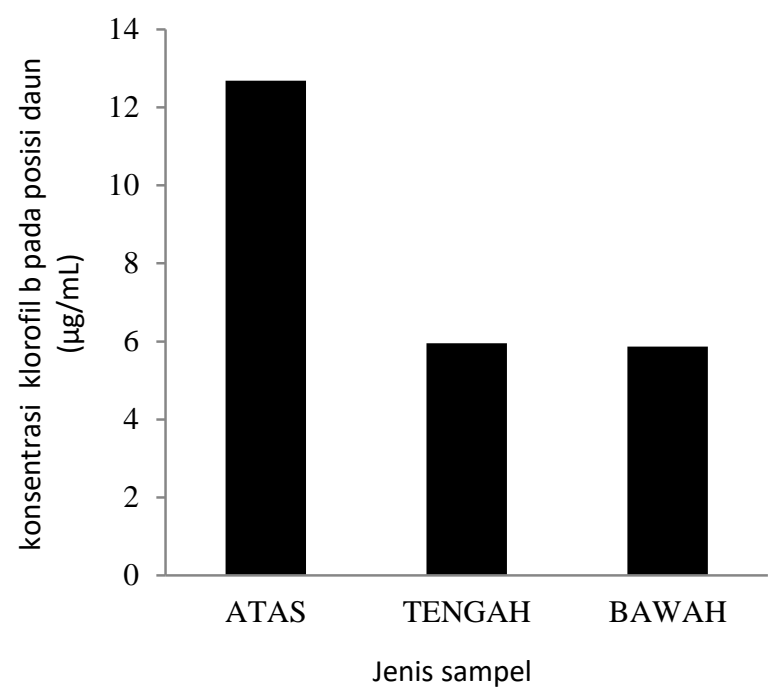

Gambar 4. Konsentrasi klorofil b pada posisi daun $(\mu \mathrm{g} / \mathrm{mL})$.

\section{Kandungan klorofil b (mg/g)}

Untuk melihat kandungan klorofil $b$ pada posisi daun, anak daun dan posisi kiri dan kanan anak daun aren dapat dilihat pada Gambar 5.

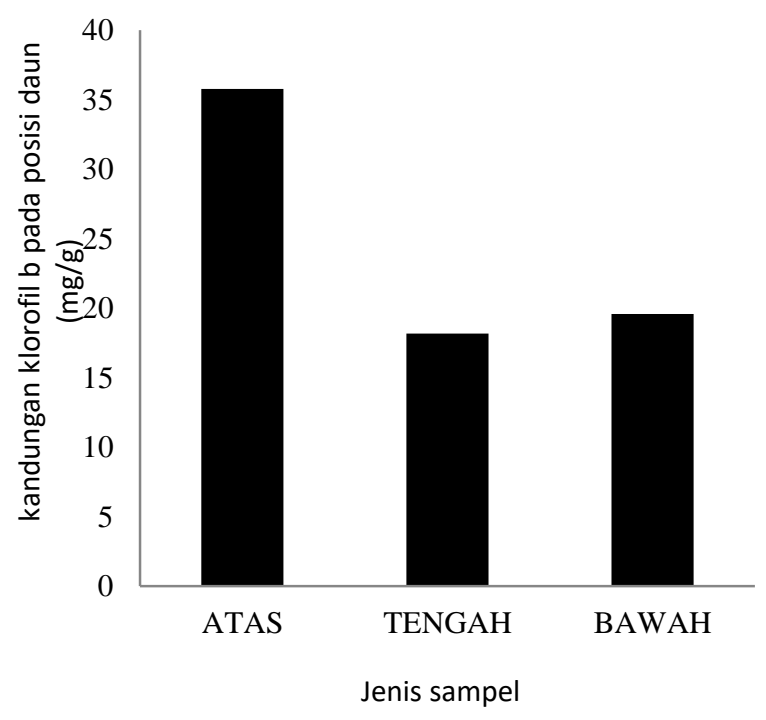

Gambar 5. Kandungan klorofil b pada posisi daun $\operatorname{aren}(\mathrm{mg} / \mathrm{g})$.

Dari Gambar 5 dapat dilihat bahwa kandungan klorofil b pada posisi daun (atas, tengah, bawah) memiliki perbedaan yang signifikan. dimana kandungan klorofil tertinggi ada pada posisi atas daun yaitu $35.796 \mathrm{mg} / \mathrm{g}$. sedangkan kandungan klorofil terendah ada pada posisi tengah daun yaitu $18,199 \mathrm{mg} / \mathrm{g}$. dari gambar 
di atas dapat dilihat bahwa kandungan klorofil $b$ pada posisi tengah dan bawah daun tidak memiliki nilai yang tidak signifikan berbeda. Sedangkan pada posisi atas, memiliki nilai yang signifikan berbeda.

\section{Kandungan klorofil b ( $\left.\mu \mathrm{mol} / \mathrm{m}^{2}\right)$}

Dapat dilihat bahwa interaksi kandungan klorofil posisi pada daun dan pada posisi anak daun terlihat berbeda. Dan juga interaksi anatara kandungan klorofil pada posisi kiri dan kanan daun terlihat berbeda. Kandungan klorofil pada posisi daun dapat dilihat pada Gambar 6 .

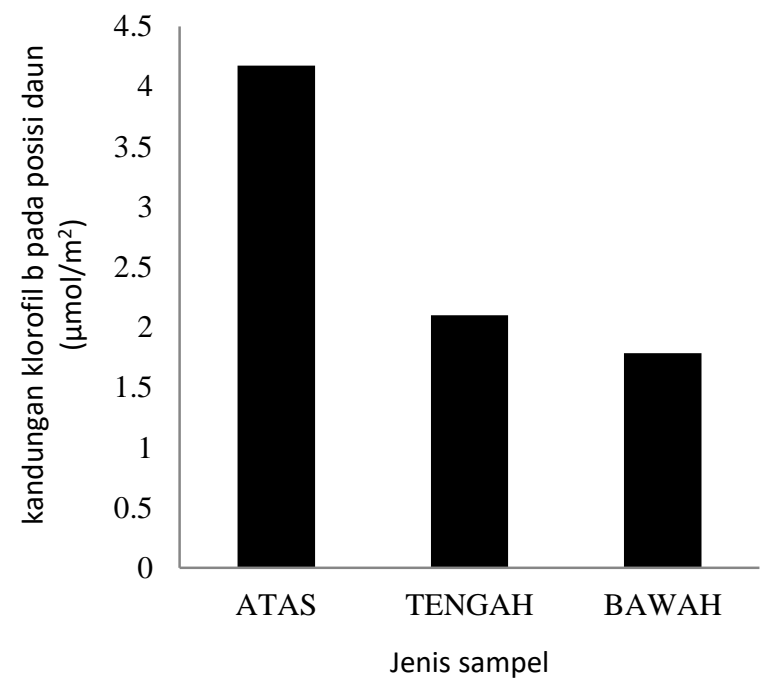

Gambar 6. Kandungan klorofil pada posisi daun $\left(\mu \mathrm{mol} / \mathrm{m}^{2}\right)$

Dari Gambar 6, dapat dilihat bahwa kandungan klorofil $\mathrm{b}$ pada posisi daun (atas, tengah, bawah) tidak memilki nilai yang signifikan berbeda. Dimana kandungan klorofil $\mathrm{b}$ tertinggi ada pada posisi atas daun, yaitu $4,174 \mu \mathrm{mol} / \mathrm{m}^{2}$. Sedangkan kandungan klorofil $\mathrm{b}$ terendah ada pada posisi bawah daun, yaitu $1,784 \mu \mathrm{mol} / \mathrm{m}^{2}$. Cahaya matahari merupakan salah satu factor yang memepengaruhi kandungan klorofil pada daun. Posisi anak daun pada daun aren yang panjang memiliki perbedaan kandungan klorofil pada masing-masing anak daun karena foton yang diserap dari cahaya matahari tidak merata karena ada bagian anak daun berada pada posisi yang lebih teduh. Kebutuhan setiap tanaman terhadap paparan cahaya matahari berbeda-beda tergantung jenis tanaman dan varietasnya (Novita dkk., 2012).

Dalam penelitian ini, terlihat bahwa posisi yang mungkin lebih banyak terpapar cahaya matahari memiliki kandungan klorofil yang lebih banyak dibandingkan dengan posisi yang teduh. Pembentukan klorofil terjadi melalui fotoreduksi protoklorofilid menjadi klorofilid a dan diikuti dengan esterifikasi fitol untuk membentuk klorofil a yang dikatalisis enzim klorofilase. Perubahan protoklorofilid menjadi klorofilid a pada tumbuhan biji tertutup (angiospermae) harus menggunakan cahaya. kemudian jenis klorofil yang lainnya akan disintesis dengan bahan awal awal dari klorofil a. Oleh sebab itu kandungan klorofil pada daun yang terkena sinar matahari yang cukup, akan membuat klorofil menjadi lebih banyak, dalam penelitian ini kemungkinan yang terpapar cahaya matahari lebih banyak adalah pada posisi atas dan ujung sehingga kandungan klorofilnya lebih banyak, sedangkan posisi tengah cenderung lebih kurang mendapatkan cahaya matahari (Pandey \& Sinha, 1979 dalam Sumenda dkk. 2011). Namun jika intensitas cahaya matahari terlalu tinggi, maka kandungan klorofil pada daun akan mengakibatkan kerusakan klorofil. Suhu yang tinggi akibat intensitas penyinaran yang tinggi dapat mengakibatkan degradasi klorofil dan memberi pengaruh terhadap aktivitas enzim klorofilase dan enzim lipoksidase (Taylor, 1984 dalam Oktaviani, 1987).

\section{KESIMPULAN}

Kandungan klorofil $\mathrm{a}$ dan $\mathrm{b}$ yang terdapat pada sampel daun aren yang dihitung berdasarkan 3 unit satuan $\mu \mathrm{g} / \mathrm{mL}, \mathrm{mg} / \mathrm{g}$ dan $\mu \mathrm{mol} / \mathrm{m}^{2}$. Kandungan klorofil a dan $b$ pada sampel pohon aren tertinggi terletak pada posisi kiri daun. Selanjutnya jumlah kandungan klorofil a sampel pohon aren posisi pada daun urutan tertinggi pada posisi atas ; bawah ; tengah. Kandungan klorofil a pada posisi anak daun pangkal memiliki urutan tertinggi pada posisi ujung; pangkal; tengah.

\section{DAFTAR PUSTAKA}

Kamagi, L., Pontoh, J. \& Momuat, L.I. 2017. Analisis kandungan klorofil pada beberapa posisi anak daun aren (Arenga pinnata) dengan spektrofotometer UV-Vis. Jurnal FMIPA UNSRAT. 6(2), 49-54.

Novita, N., Soverda, N. \& Gusniwati. 2014. Pengaruh naungan terhadap kandungan klorofil daun dan hasil dua varietas tanaman kedelai (Glycine $\max$ L. Merill). Jurnal Program Studi Agroteknologi. 6(3), 188196.

Oktaviani, L. 1987. Perubahan-perubahan yang terjadi pada ekstrak warna hijau daun suji (Pleomele angustifolia) selama 
penyimpanan. Skripsi. Bogor: Fakultas Teknologi Pertanian, Institut Pertanian Bogor.

Porra, R.J. \& Kricdeman, P.E. 1989. Determination of accurate extinction coefficients and simultaneous equations for assaying chlorophylls $\mathrm{a}$ and $\mathrm{b}$ extracted with four different solvents: verification of the concentrationof chlorophyll standads by atomic absorption spectroscopy. Biochemical et Biophysica Acta. 75, 34-38.
Sapari, A. 1994. Teknik pembuatan gula aren. Surabaya: Karya Anda.

Sumenda \& Lusia. 2011. Analisis kandungan klorofil daun mangga (Mangifera indica $\mathrm{L}$ ) pada tingkat perkembangan daun yang berbeda. Jurnal Bioslogos. 1, 20-24.

Voet, D., \& Voet, J.G. 1990. Biochemistry. New York: John Wiley \& Sons Inc. 